\title{
O respeito á magistratura e o res- peito á liberdade de defesa $\left(^{*}\right)$
}

\author{
J. M. de Azevedo Marques \\ "Il n'y a pas possibilité de défendre \\ sans attaquer" \\ (Decisão da Côrte Suprema de Paris)
}

Verdade essa intuitiva que a Côrte civilizada de Paris proclamou, mas que nem sempre, entre nós, tem sido bem compreendida.

A observação reiterada, durante quatro anos na presidência desta secção da Ordem dos Advogados, levou-me a refletir muito, relativamente a queixas contra palavras e conceitos emitidos por advogados, em autos, supostamente desrespeitosos de magistrados.

Cumpre estabelecer as teses que conciliem o respeito devido á magistratura com o respeito devido á defesa de direitos, defesa que é um dever essencial do advogado, dever que, entretanto, se não cumpre sem liberdade. Liberdade que se não exerce sem golpes contra golpes. A questão está no modo e na bôa fé do golpe, que o talento e a educação devem saber desferir.

Disse bem o célebre advogado Cartier, defendendo o

(*) Estudo do presidente da Ordem dos Advogados, Secção de S. Paulo, oferecido ao ilustre colega Dr. Waldemar TeIXeIRA DE Carvalyo. O Conselho o aprovou mandando publicar. 
conhecido politico e advogado Sr. Viviani, acusado de desrespeito a juiz, ou ao ministério público: "E como se um dos duelistas pudesse usar da sua espada, livre, porém, do golpe do outro" Ora, isso não é possivel, nem justo. 0 nosso Código de Ética Profissional dispõe:

Secção I, n. 1. - “Os deveres do advogado compreendem: o zêlo da dignidade da magistratura"

Secção III, n.' II. - “Nenhum receio e desagradar a juiz deterá o advogado no cumprimento de seus deveres"

Secção V, n.o I. - "Deve o advogado: a) tratar as autoridades do juizo com respeito, discreção e independência"

Esses textos dizem muito e dizem nada. Não estivessem impressos no código e estariam vivos nas sociedades civilizadas como o Brasil. "Zêlo da dignidade da magistratura"; "nenhum receio de desagradar a juiz"; "tratar as autoridades do juizo com respeito", são axiomas genéricos, preexistentes na conciência e no próprio interesse dos advogados.

Será que a luta judiciária é sempre e só entre advogados?

Será que os juizes sejam sempre e só pacíficos, imparciais, indiferentes, infaliveis, sábios? A afirmativa decorreria de divindades.

Os magistrados tomam parte na luta judiciária, pois concèdem a um e negam a outro, quer no curso do processo, quer na decisão final. E notadamente nos recursos o ataque do recorrente é direto contra a decisão, mas, nem por isso, se deduz a intenção de ofender o seu prolator, ataque esse que é um direito de defesa. Será falso raciocínio pretender que $o$ ataque á decisão seja ataque ao seu autor. Quando o crítico ataca uma horrivel obra de arte, pintura, escultura, música, poesia, necessariamente está atacando impiedosamente o artista que a fez mal, mas sem ultrajar-lhe 
a dignidade pessoal. A piedade não é indispensavel na critica. Os julgamentos judiciários são obras de arte, ás vezes maravilhosas, ás vezes detestaveis.

Mesmo nos procedimentos administrativos do juizo, nas medidas provisionais, por exemplo, nos desquites amistosos, nos inventários, nos protestos e interpelações em geral, nas suspeições, na habilitação de nubentes, nas curadorias de ausentes, nas subrogações, e tantos outros, sem controvérsias, os juizes, necessariamente, lutam para um ideal, que a sociedade lhes confia e que deve ser, mas nem sempre é, construtivo. Agir é lutar; ha lutas unilaterais. Se lutam, podem prejudicar, podem negar o que é inegavel, podem desconhecer o que é evidente, ignorar o que não deviam ignorar, podem, emfim, errar crassamente, prejudicialmente, e ofendem e lesam. E então? Então, ha de a vítima ficar impassivel em seus nervos humanos? O advogado, identificado com a vítima e cheio de responsabilidades, apaixonado pelo direito, que defende, não ha de atacar a entidade impessoal, juiz, que é diferente do individuo $\mathrm{Fu}$ lano? Tanto mais que o advogado é, como o juiz, "um funcionário do tribunal e não somente um mandatário da parte" na frase do eminente juiz americano SHaswoon, subscrita pelo nosso eminente Ruy Barbosa.

O defensor de um direito, injustamente negado, ha de calmamente procurar no fundo da sua pena, ou da sua palavra, o mais assucarado mel para refutar golpes injustos ou ilegais?

O magistrado não é um santo perante fanáticos. Como encarnação da Justiça, o magistrado é impessoal, é um servidor da lei, servidor da humanidade juridicamente organizada; não é um rival do advogado. Assim o considerei para mim quando fui magistrado.

Mas, a missão social do advogado não é inferior, não é subalterna; não deixou de ser, o que sempre foi: um servidor do Direito, da liberdade e da personalidade humana, colaborador do juizo, órgão e função social indispensavel, cuja antologia deve sobreviver. Os advogados trânsfugas 
da virtude e da honra não entram em linha, não são advogados de verdade. Sendo assim, como evidentemente é, a magistratura tem direito indiscutivel ao respeito por parte de todos, inclusivamente dos advogados, como estes teem direito ao respeito de todos, inclusivamente dos magistrados. Axioma este, entretanto, que não exclue o ataque ás sentenças injustas.

"O advogado não se deterá diante do receio de desagradar a juiz" di-lo O NOSSO CóDIGO DE ÉTICA PROFISSIONAL.

Que mais poderá “desagradar a juiz" do que impugnar decisões suas e, portanto, acoimá-las de desacertadas, injustas, errôneas, desatentas, etc? Mas, que outra maneira haverá de defender direitos negados? Assim criticando, nem por isso se desrespeita a honorabilidade do magistrado, sempre presumivel.

Ora, isso é permitido pelo Código de Ética Profissional que, mui expressivamente, aconselha aos advogados: "não se deterá" Esta frase: "não se deterá" é vibrante.

A expressão "ataque" sôa mal aos ouvidos profanos. Mas, no caso, não é, não deve ser, equivalente de ofensa, afronta, ou injúria a uma individualidade. $\mathrm{O}$ ataque defensivo, no campo da guerra judiciária, não deve ser qualquer coisa que constitua delito criminal definido nas leis penais comuns. O "ataque", no caso, é a contradita cuja energia não desnatura a liberdade de defesa, ao contrario, lhe é necessária. Nem na lide judiciária se trata de individualidades Fulanos juizes, mas tão só de juizes sem Fulanos. juiz perde o seu nome de batismo quando decide, perde a sua sensibilidade, não passa de um abstração. É uma nobre efígie. Mas, o que cumpre estabelecer firmemente é: quando a atitude do advogado deixa de ser independente para se tornar desrespeitosa; ou, por outra, até que ponto pode. ir o ataque contra despachos ou sentenças.

No sístema de processo verbal é mais dificil precisar regras, porque a moderação e a quietude na discusâo oral são impossiveis no ardor da peleja, o que constitue um dos 
grandes inconvenientes da oralidade processual. Realmente, o imprevisto e a surpresa nas discussões desnorteiam, mas não deixam golpes profundos. Disse um escritor: "O discurso é como uma ânfora destampada cujo perfume se evapora", e um outro disse: - "Os discursos judiciários só interessam aos clientes, e algumas vezes aos juizes." E' outro inconveniente do processo oral.

Mas, no processo escrito bem se poderá evitar excessos e medir expressões amargas.

Todavia, mesmo no processo escrito, ha momentos em que toda a prudência se esgota, e a mão que escreve voa como a palavra que fala.

Os exemplos elucidam. Eis alguns:

1..$^{\circ}$ - Em fôro do interior do país, o juiz induz um institor subserviente a requerer a tutoria de um menor de cinco ou seis annos de idade, que tinha pai, contra o qual nada existia alegado nem provado, senão futilidades. E, sem siquer ouvir a esse pai, investe o requerente na tutela do menor e, á força, fá-lo retirar dos braços paternos! A vitima corre a um advogado, o qual, nada conseguindo de viva voz, requer contra o ato. 0 juiz mantém a violência. $O$ advogado replica energicamente escrevendo, entre outras, as frases seguintes: " $O$ ato é, além de ilegal, imoralissimo, por ser público e notório na comarca a indisposição do prolator contra esse pai de quem não conseguiu umas terras que desejava possuir" "Mera vingança" Esse advogado, identificado com o cliente, vibrando de indignação, desmoralizadú pelo insucesso da sua intervenção profissional, é, evidentemente, compartícipe da dor daquele desvairado pai, esse advogado, perguntamos, excedeu-se no ataque? violou a ética profissional? é passivel de censura? Não me parece. Para afirmá-lo seria necessário desconhecer a natureza humana. $O$ golpe desferido por êle não foi maior do que o desferido pela decisão. Golpe contra golpe foi o que houve em perfeita proporção, dentro de autos, que, em geral, só os litigantes conhecem, circunstância esta relevante quando se cogita dos delitos contra a honra e bôa fama. 
2. $)$ - Num executivo hipotecário o devedor alega, em embargos, a nulidade da hipoteca por lhe faltar, inicialmente, a assinatura da sua mulher. Esta, porém, em depoimento pessoal, afirma que conhecia desde inicio a hipoteca com a qual concordava, ratificando e confessando. O juiz, entretanto, julga nula a hipoteca e absolve o devedor não só do accessório como até mesmo da dívida! Erro crasso, revoltante. 0 advogado, em recurso, ataca a decisão causadora de enormes prejuizos pela demora e pela depreciação do imovel garantidor. E, atacando, escreve: "quanta ignorancia do direito!"; "quanto descaso pelo dinheiro alheio"; "quanta ladroice!" As duas primeiras invectivas tocam ao juiz, mas a última, que é mais grave, deixa em suspenso a intenção do advogado, porque a "ladroice" não é atribuida ao juiz, mas, sim natural e logicamente, ao devedor relapso e vitorioso. Seja, porém, como fôr, não houve injúria, ou desrespeito á individualidade do juiz, cujo nome não se declara, cuja pessoa fica resguardada pela toga impessoal, cuja decisão é erradíssima, mas cujo prolator será honradíssimo.

Eu não teria escrito desse modo a impugnação, teria dito diferentemente, mas não posso exigir que todos tenham a mesma flêugma, a mesma idade, o mesmo temperamento. Não vejo enfim naquelas palavras intenção de faltar ao respeito á pessoa individuada do magistrado. Eu separo a individualidade - criatura humana - do personagem - juiz; eu despersonalizo, desde que o nome do magistrado não é revelado pelo ataque.

Cumpre não esquecer, o juiz aí, absolvendo o devedor implicitamente atacou o credor atribuindo-lhe o propósito de receber dinheiro indevido: quem cobra o que é incobravel, pratica ato incompativel com a honestidade. Igualmente, quando o tribunal superior reforma a sentença do inferior declara, implicitamente, que tal sentença era injusta, ou errônea, ou violadora da lei; e entretanto não ofende.

3.') - Apresentamos agora um exemplo de falta punivel do advogado; é o seguinte: - Em arrazoado, o advo- 
gado escreveu: - "a decisão do juiz dr. Fulano foi proferida por interesse ou ligação pessoal que êle tem com o autor, ou réu, de quem é amigo íntimo, ou inimigo, etc.". Eis aí um ataque á dignidade individual, um desrespeito a um magistrado, individuado.

Por outro lado, cumpre tambem não esquecer, o ataque, sem injúria, escrito nos autos, fiel á verdade jurídica, é uma válvula de escapamento. 0 ataque escrito satisfaz só por só; evita, quasi sempre, piores reações. E' preferivel escrever criticas em autos, que jazem nos esconderijos de cartórios e ficam amortecidos, do que verberar de viva voz, de casa em casa, de amigo a amigo, de colega a colega, de cartório a cartório, de club a club, e nos corredores do Palácio, e nas ruas, e nas reuniões, com deturpações, com paixão incontida. $O$ essencial é que o ataque seja merecido, e de bôa fé. Dizer a verdade é um desafôgo.

No recente e magnífico livro do ilustre dr. Mário GuIMARÃES DE Souza, intitulado "O Advogado", escrito para concurso na Faculdade de Direito do Recife, em 1935, encontramos os conceitos seguintes:

"Nada mais humano do que a revolta do litigante derrotado. Seria uma tirania exigir que o vencido se referisse com meiguice e doçura ao ato judiciário e á pessoa do julgador que lhe desconheceu o direito. $O$ protesto ha de ser, por fôrça, em temperatura alta. O juiz é que tem de se revestir da couraça da insensibilidade profissional necessária para não perder a calma e não cometer excesso" (É transcrição de uma decisão do notavel juiz Raphael Magalhães, de Minas-Geraes) (pag. 261).

Por suas próprias palavras escreve o dr. MARIo G. DF. Souza :

“Exigir que o advogado não vibre nem se in- 
flame na defesa do interesse que lhe está confiado e que muitas vezes representa a felicidade de uma família, a liberdade de um cidadão, o patrimônio de uma viuva, a legitimação de uma criança, é desconhecer a natureza humana.

Infelizmente essas idéias, que são as verdadeiras, ainda não estão devidamente assimiladas por certos magistrados que, do alto dos seus tamancos, tratam os advogados de superior para inferior e não toleram a mais ligeira crítica aos seus despachos" (pags. 263 e 264).

Dificil, certamente, é o problema, porque ha a considerar-se que nem todas as decisões são atacaveis por injustas, ilegais, errôneas, arbitrárias, etc. Ha, com efeito, decisões justíssimas, porque ha demandas injustificaveis, ha demandistas de má fé, haverá advogados inescrupulosos, ha aventuras judiciárias, variações essas que tornam delicada a classificação dos ataques. O simples êrro do magistrado, em completa bôa fé, mesmo a sua ignorância da dificil ciência juridica, não justificam, em regra, um ataque mais apaixonado, senão uma crítica enérgica para despertar o próprio prolator, ou os revisores da sentença a uma melhor meditação.

Admitem-se no advogado recriminações vulgares, por exemplo: "A decisão proveiu de não conhecer o Direito"; "a decisão resultou de não terem sido lidos os autos conveniente e completamente"; "a decisão não atendeu ao documento tal, que é decisivo"; "a sentença é errônea em face da lei"

O grande advogado que foi o professor João Monteino, cuja bôa educação hombreava com a energia na defesa de direitos, escreveu em autos o seguinte:

“E com a maxima franqueza dizemos que o voto vencido é contraditório, injurídico, e descon- 
soante a prova dos autos" (Proc. Civ. e Com. 1." ed., vol. 3, pag. 248).

E um ataque violento, mas não ofensivo do prolator do voto vencido.

O exame dos autos, nem sempre o magistrado faz com o mesmo cuidado e meticulosidade com que o faz o advogado. Conta-se um caso ocorrido n'um superior tribunal do país, que é este: Julgando últimos embargos, o relator começou dizendo que os rejeitava porque "ha nos autos um documento que prova cabalmente tal fato, o qual resolve a controvérsia" O advogado embargante, que assistia á discussão, violando o regimento, levanta-se da platéia e ousadamente pede licença para contestar aquela afirmação equivocada, pois não havia nos autos tal documento. $O$ relator zanga-se com o aparte insolente e insiste na afirmação. Os outros julgadores, nenhum dos quais havia revisto os autos, zangam-se tambem. Mas um deles intervém e pede ao seu colega relator o fayor de ler o documento. O relator procura-o demoradamente nas páginas dos autos e verifica não existir. E então, nobremente, declara que se havia enganado confundindo esses autos com uns outros de questão análoga onde havia um certo documento; e volta atrás no seu voto para modificá-lo inteiramente, recebendo os embargos e assim dando ganho de causa a quem ia perdê-la se não fôra a energia audaciosa do advogado. Quanto lucrou a Justiça com esse desrespeito! Quanto se engrandeceram esses magistrados!.

Por coinciđência, no momento em que estamos escrevendo estas pobres linhas, lemos nos jornais a notícia de uma decisão, em data de ante-ontem, no Supremo Tribunal, a propósito da qual o ilustre Ministro, Dr. Octavio KelLY, disse: "Os advogados podem escrever o que bem entenderem nos autos em favor de seus constituintes, sem responsabilidade criminal; cabendo entretanto ação para mandar riscar as injúrias e calúnias porventura exaradas, bem como para imposição da multa." É uma opinião valiosa, de máxima autoridade, que nos tranquiliza e com prazer registramos. 
Sob outro prisma fundamental vale a pena considerar a diferença entre a vida do juiz e a do advogado: aquele. soberano na sua palavra decisória e, por isso, calmo e confortado no remanso do sell ninho, sem combatentes pela frente; este, o advogado, sempre na luta, precipitando-se aqui e ali, dia e noite, rodeado de adversários naturais e artificiais. Por isso, exclamou um velho advogado: "Oh! como é pesado e duro o fardo de uma convicção, cheio de angústias, perigos e incertezas!. ." Sofrimentos e martírios, sim, que o conturbam, dos quais os juizes não se apercebem na tranquilidade da sua vida profissional, sabendo que terão a louvá-los e aplaudí-los os litigantes vitoriosos. Ao passo que o advogado não raro adquire mais um desafeto no próprio cliente vencido. Em geral o público displicente acredita que o advogado não tem uma sensibilidade que deprime o seu organismo moral, inteletual e físico. Puro êrro. Em seu coração ha feridas silenciosas, invisiveis, que sangram ao ouvir a sentença contrária, inesperada, fazendo-o duvidar de tudo, de todos e de si mesmo.

Falamos sempre dos advogados honestos e capazes; não dos trânsfugas. Estes não recusam, antes engendram litígios indefensaveis, contra a honorabilidade e a lei; aqueles, porém, defendem gratuitamente as causas defensaveis, se o cliente não pode retribuir.

Na observação de um escritor, a profissão do advogado é a que mais cêdo lhe imprime na face o estigma de uma senectude precoce e de uma fadiga incuravel. E um professor de medicina, dizia que o advogado não escapa á hepatalgia!

Nessas condições da Natureza como exigir da pena do advogado só palavras doces, a título de respeitosas, contra arestos injustos ou errôneos, que não são individualidades?

Bem sabemos, a figura legal da completa perturbação de sentidos do advogado não caberia, mas, no caso especial, pode-se admitir certa modalidade sui generis dessa escusa para conciliar o respeito á liberdade de defesa de direitos com o respeito á magistratura. O certo é que a energia na 
defesa de direitos não constitue, só por só, a intenção criminosa, sem a qual não ha delito punivel.

Está subentendido que não cogitamos de decisões e atos manifestamente legais, justos, acertados, que os ha felizmente e abundantes, os quais a ilustração dos advogados vencidos não pode desclassificar. Para esses, na contradita, cabem as palavras doces, que o talento e até mesmo o pudor do causidico sabem compôr.

$O$ assunto é delicado e não temos a pretensão de fixá-lo de vez. Apenas pedimos a melhor atenção dos ilustres colegas e magistrados em benefício das recíprocas relações de fraternidade e de decôro do fôro, e da finalidade da Ordem dos Advogados. Em resumo pensamos, salvo melhor juizo, que são verdadeiras as teses seguintes:

1 - O respeito devido á magistratura não exclue o respeito á liberdade de defesa;

2 - A liberdade de defesa jamais deve equivaler ao ataque injurioso ou ultrajante á pessoá individuada do juiz;

3 - A liberdade de ataque é permitida pela ética profissional contra decisões judiciárias, consideradas injustas, a juizo do advogado, porém sem menção dos nomes dos seus prolatores e sem incidência nos delitos do Direito comum;

4 - No processo oral é menos rigorosa do que no escrito a apreciação das palavras da defesa e da intenção do orador.

S. Paulo, 19 de Junho de 1938. 